Assiouras, I., Skourtis, G., Giannopoulos, A., Buhalis, D., Koniordos, M., 2019 Value Co-Creation effect on Customer Citizenship Behavior, Annals of Tourism Research, Vol 78. https://doi.org/10.1016/j.annals.2019.102742

\title{
Value co-creation and customer citizenship behavior
}

\begin{abstract}
Drawing on social exchange theory and the service-dominant logic framework this paper explores the association between value co-creation and the willingness to engage in customer citizenship behavior in the hospitality and tourism context. Tourism and hospitality firms are increasingly offering opportunities for co-production and value-in-use not only to increase revisit and repurchase intentions but also to benefit from manifestations of customer citizenship behavior such as customer feedback, advocacy, customer-to-customer assistance and tolerance in less satisfactory future services. The paper offers a building block for future work to investigate the causal relationship between the dimensions of value co-creation (co-production and value-in-use) and customer citizenship behavior.
\end{abstract}

\section{Keywords}

value co-creation, customer citizenship behavior, social exchange theory, hospitality services, tourism industry 


\section{Introduction}

Tourism and travel experiences "often extend well beyond temporary sojourns and the consumption of place” (Mostafanezhad \& Norum, 2018, p.131). A holistic experience approach with coordination of the prior, during and after trip phases is critical (e.g. Prebensen, Vittersø \& Dahl, 2013). This includes customer-to-customer interaction and extra-role positive behavior, like sharing the experience among family, friends, strangers or the company itself (McCable \& Stokoe, 2010; Jansson, 2018). The global expansion of media tech-savvy travellers urge tourism and hospitality organisations to compete fiercely, not only for tourists' expenditure, but also for aspects of customer citizenship behavior, such as share of voice and mind (Park \& Nicolau, 2017). To meet this goal, tourism and hospitality organizations are increasingly adopting the logic of value co-creation (Neuhofer, Buhalis \& Ladkin, 2015; Rihova, Buhalis, Gouthro \& Moital, 2018; Rihova, Buhalis, Moital \& Gouthro, 2015).

The umbrella concept of value co-creation assumes that consumers take an active role and co-create value together with the firm, employees and other customers (Ranjan \& Read, 2014). This is something that has been highlighted in the literature of services (e.g. Mills \& Moberg, 1982; Kelley, Donnelly \& Skinner, 1990) and tourism (e.g. Smith, 1993) long before the appearance of service-dominant logic and value co-creation in the marketing literature. Under the service-dominant logic, the tourism industry is a service ecosystem. Actors are resource integrators connected by shared institutional arrangements and mutual value creation through service exchange (Vargo \& Lusch, 2016). The experiential nature of tourism and hospitality calls for value co-creation (Chen, 2016; Tung, Chen \& Schuckert, 2017) through critical participation and collaboration of tourists with service providers (Binkhorst \& Den Dekker, 2009) as well as with other tourists (e.g. Rihova et al., 2015, 2018). The degree of cocreation is related positively to customers' evaluations of new services (Xu, Liu \& Lyu, 2018) and it has positive relationship with willingness to pay ( $\mathrm{Tu}$, Neuhofer \& Viglia, 2018). However, there is scarcity of research regarding the role of value co-creation as an antecedent of willingness to engage in customer citizenship behavior.

The primary goal of this research is to explore the strength of association between the dimensions of value co-creation (co-production and value-in-use) and travellers' willingness to engage in customer citizenship behavior in future encounters with the hospitality and tourism organization and other travellers as well. This paper adopts social exchange theory to take a closer look at the two-way interactions between guests and tourism and hospitality service providers (e.g. micro-level of service ecosystem). It explores the possible 'give and take' reciprocal character, which is of critical importance in the tourism and hospitality context 
(Chen, 2016; Tung et al., 2017). Moreover, the study explores the possible mediating role of customer satisfaction in the relationship of value co-creation and travellers' willingness to engage in customer citizenship behavior. This paper offers a building block (Dolninar \& Ring, 2014) for future work to investigate the causal relationship between the dimensions of value co-creation (co-production and value-in-use) and customer citizenship behavior.

\section{Theoretical Background}

\section{Customer citizenship behavior}

Customer citizenship behavior is defined as "voluntary and discretionary behaviors that are not required for the successful production or delivery of the service but that, in the aggregate, help the service organization overall" (Groth, 2005, p.11). Customer citizenship behavior pertains to extra-role behaviors that include actions towards other customers, employees and/or firms. Yi and Gong (2013) argue that customer citizenship behavior has four dimensions: feedback (customer information directed to the employees); advocacy (recommending the firm to others, third parties, etc.); helping (provision of assistance from customer to customer) and tolerance (customer readiness to show patience in case of service failure). In the tourism and hospitality context, customer citizenship behavior may pertain to the case of a tourist who might share a positive experience (e.g. friendly hotel staff) with friends and relatives (offline or online). They may write positive reviews using online platforms (e.g. TripAdvisor) and even provide useful and creative ideas on how the check-in process might be improved. They can also create electronic word of mouth and induce user generated content that can support the competitiveness of the organisation (Williams, Ferdinand, Inversini, Buhalis \& Viglia, 2016; Williams, Inversini, Buhalis, \& Ferdinand 2017; Viglia, Minazzi \& Buhalis, 2016).

Customer citizenship behavior provides significant benefits to firms, the customers themselves and other customers. For instance, organizational performance is improved by customer citizenship behavior through enhanced relationships among participants in the service encounter (Yi, Nataraajan \& Gong, 2011). It adds value to customers by increasing the sense of belonging and being useful, providing relief from friends and relatives or other duties, social interaction by assisting and meeting other customers, dealing with employees in a respectful manner and assisting staff and consumers without anticipating any direct reward (Rihova et al., 2015; Van Doorn, Lemon, Mittal, Nass, Pick, Pirner \& Verhoef, 2010). Previous research led to the study of its potential antecedents (customer-related, firm-related, and other-customerrelated factors) and consequences (perceived service quality, customer satisfaction, customer 
loyalty, employee performance, employee satisfaction and loyalty) (Bove, Pervan, Beatty \& Shiu, 2009; Yi et al., 2011). For example, Dang and Arndt (2017) investigate the personal costs that may inhibit the decision to engage in such behavior. Other studies reveal that customer citizenship behavior has a negative relation with the customer's turnover intention (RevillaCamacho, Vega-Vázquez, \& Cossío-Silva, 2015). The positive effects of customer citizenship behavior on both a firm and customers are evident across the literature (see e.g. Chan, Yim \& Lam, 2010).

In the tourism and hospitality industries, the majority of studies focus on employee citizenship behavior (e.g. Chen, 2016). For instance, Nadiri and Tanova (2010) examine the relationship of organizational justice with organizational citizenship behavior, turnover intentions, and job satisfaction. Yet, the construct of customer citizenship behavior has not been well investigated from the tourist's perspective. There are few studies that explore some of its antecedents such as loyalty (Zoghbi-Manrique-de-Lara, Suárez-Acosta \& AguiarQuintana, 2014), emotional experience (Zhang, Gordon, Buhalis \& Ding, 2018) and some consequences like guest satisfaction, loyalty, and perceived value (Tung et al. (2017) in differing contexts such as package tour and destination marketing (Liu and Tsaur, 2014). However, some customer citizenship behavior dimensions have been investigated separately in different studies. For example, advocacy has been investigated in numerous studies (e.g. Lam \& So, 2013) with the resultant findings showing its positive impact on increasing hotel occupancy rates (Viglia et al., 2016).

\section{Value co-creation}

Value co-creation can be defined as the actions of multiple actors, who are often unaware of each other, that contribute to each other's wellbeing (Vargo \& Lusch, 2016). Value co-creation has been examined in various domains (e.g. Grönroos \& Voima, 2013) indicating that it has broad theoretical dimensions. Co-production and value-in-use (Lush \& Vargo, 2006; Ranjan \& Read, 2014), is are both actually referred to as value-in-context (Vargo \& Lusch, 2016), as the latter is always context dependent. Co-production (Chan et al., 2010) occurs when customers share information, make suggestions and become involved in decision-making. Coproduction is analyzed across three dimensions, namely: knowledge sharing, equity and interaction (Ranjan \& Read, 2014). Sharing happens when consumers' knowledge, ideas and creativity are used during the value creation process (Zhang \& Chen, 2008). Many practices encapsulate a plethora of human activities and interactions, linked to shared experiences between employees and customers, family and friends (Rihova et al., 2018). Examples include 
cooking a campsite meal, participating in a festival, undertaking together a range of hotel animation activities or helping cooking in a hotel barbeque event, etc. Equity is related to the firm's decision to share control of the value creation process with consumers (Hoyer, Chandy, Dorotic, Krafft, \& Singh, 2010). Interaction refers to participation, dialog (Payne, Storbacka \& Frow, 2008) and engagement (Zhang \& Chen, 2008).

According to the service-dominant logic, value is considered a "dynamic, situational, meaning-laden and phenomenological construct that emerges when customers use, experience or customize marketers' value propositions in their own experience contexts" (Rihova et al., 2015, p. 357, Vargo \& Lush, 2016). Ranjan and Read (2014) propose three dimensions: experience, relationship, and personalization. Experience is related to consumers' psychical, cognitive and affective liking of the artifact of products of services (Edvardsson, Gustafsson \& Roos, 2005). Personalization occurs when the value being contingent on individual characteristics and relationship manifests itself in the form of collaboration, engagement and reciprocity (Ranjan \& Read, 2014; Neuhofer et al., 2015). Text analytical approaches to a large quantity of consumer reviews demonstrate the association between guest experience and satisfaction, suggesting that these two domains of consumer behavior are inherently connected (Xiang, Schwartz, Gerdes \& Uysal, 2015). This study adopts the term value-in-use to be in accordance with the scale of Ranjan and Read (2014), following nevertheless the evolution of the term towards the value-in-context conceptualization (Vargo \& Lusch, 2016) as value is always context dependent.

In the tourism and hospitality context, both empirical (e.g. Grissemann \& StokburgerSauer, 2012, Mathis, Kim, Uysal, Sirgy \& Prebensen 2016; Prebensen \& Xie, 2017) and theoretical insights (Binkhorst \& Den Dekker, 2009; Cabiddu, Lui \& Piccoli, 2013; Sfandla \& Björk, 2013; Rihova et al., 2015, 2018) confirm the importance of value co-creation. The role of value co-creation is deemed both critical and complex in the tourism and hospitality context (Rihova et al., 2018). This is because value co-creation exists before, during and after the trip (Prebensen et al., 2013) and embraces a social interactive format (e.g. with other guests, frontline employees, managers, family members). The degree of co-creation has a positive relationship with customers' evaluations of new services (Xu et al., 2018) and positively influences their willingness to pay (Tu et al., 2018). Employees' positive psychological capital is related to value co-creation (Lee, Hsiao \& Chen, 2017); and customers' information and emotional participation in services is related to employees' innovative behavior (Li \& Hsu, 2018; Stamolampros, Korfiatis, Chalvatzis \& Buhalis, 2019). 
The investigation of co-creation at the destination level offers interesting insights, engendering the sense of ownership and empowerment for the community (Hamilton \& Alexander, 2013). Ross, Saxena, Correia and Deutz (2017) emphasize the importance of the co-creation perspective to create memorable creative tourism experiences by utilizing archaeological heritage. Other studies focus on the role of co-creation on the authenticity of music festivals and heritage sites (Bryce, Murdy \& Alexander, 2017; Rihova et al., 2015, 2018; Szmigin, Bengry-Howell, Morey, Griffin \& Riley, 2017) or the importance of co-creation in creative tourism experiences alike (Tan, Kung \& Luh, 2013).

\section{Conceptual Framework and Hypotheses}

Relevance of social exchange theory to value co-creation in the context of customer citizenship behavior

Value co-creation and specifically co-production involve consumers as co-workers or prosumers who "undertake value creating activities that result in the production of products they eventually consume and that become their consumption experiences" (Xie, Bagozzi \& Troye, 2008, p. 110). Social exchange theory is one of the most influential theories from the workplace behavior (Cropanzano \& Mitchell, 2005). Research efforts unveil the theoretical underpinnings of social exchange theory to advance the field of value co-creation and its relationship with customer retention (Preikschas, Cabanelas, Rüdiger \& Lampón, 2017).

The core theoretical assumption of social exchange theory is that all social life can be investigated as an exchange of tangible and intangible rewards and resources between/among actors (Homans, 1961) on the grounds that "all relationships have 'give and take," (Kaynak \& Marandu, 2006, p. 229). "Social exchange comprises actions contingent on the rewarding reactions of others" (Cropanzano \& Mitchell, 2005, p. 890). Social exchange theory holds that as actors interact over time (e.g. customer-employee), they experience the need to reciprocate the support and assistance of the other person (Blau, 1964). Reciprocity refers to the feeling of obligation to reciprocate, when an individual perceives benefits from another party's actions (Tung et al., 2017). Thus, social exchange theory is based on the premise that actors' actions are contingent upon other actors' behavior (Coulson, Maclaren, Mckenzie \& O'Gorman, 2014). Over time, the reciprocity leads to "mutually and rewarding transactions and relationships" (Cropanzano \& Mitchell, 2005, p. 890).

Applying social exchange theory to the frame of value co-creation, it is plausible to expect that the consumers will have a sense of obligation in the form of extra-role behaviors. The sense of belonging acts as a catalyst to joint activities, in cases where the interaction 
rewards each participant (Roberts, Hughes \& Kertbo, 2014). In customer-employee interactions, some researchers have argued that from a customer's perspective, giving back is demonstrated through customer citizenship behavior (Chen, 2016). Guests who receive high value from hotel experience simply return the "favor" or sustain these "rewarding transactions and relationships" with the hospitality service provider (Cropanzano \& Mitchell, 2005, p. 890), demonstrating a higher level of customer citizenship behavior. Literature on experience and personalization argues that guests who are feeling recognized and treated in a personal and unique way provide positive feedback. They also repeat visitation and increase advocacy through word-of-mouth and personal recommendation (e.g. Barnes, Mattsson, \& Sørensen 2014; Neuhofer et al., 2015).

According to Blau (1964), the motives/rewards for a customer citizenship behavior can be intrinsic (e.g. respect, affection) or extrinsic (e.g. money, free accommodation). Thus, guests might provide some feedback to hotel employees about either the positive or the negative aspects of the service rendered because they would like to receive a better service (e.g. intrinsic reward). The reciprocity of social exchange theory could be demonstrated through positive word-of-mouth. Guests may write positive online reviews, share their experiences on social media or face-to-face with friends and relatives because they feel good about that experience (e.g. intrinsic motive). Helping other guests either during the visit or for a future stay in the hotel may be another act of reciprocity towards the hospitality organization, which can have extrinsic (e.g. expect a reward from the hospitality firm) or intrinsic motives (e.g. getting an emotional reward by helping someone that needs help). Figure 1 assumes that value in use and co-production are associated to value co-creation, guest satisfaction and willingness to engage in customer citizenship behavior.

H1. Value co-creation has a relationship with guests' willingness to engage in customer citizenship behavior.

Figure 1: Conceptual model: the role of value in use and co-production in value cocreation, guest satisfaction and willingness to engage in customer citizenship behavior.

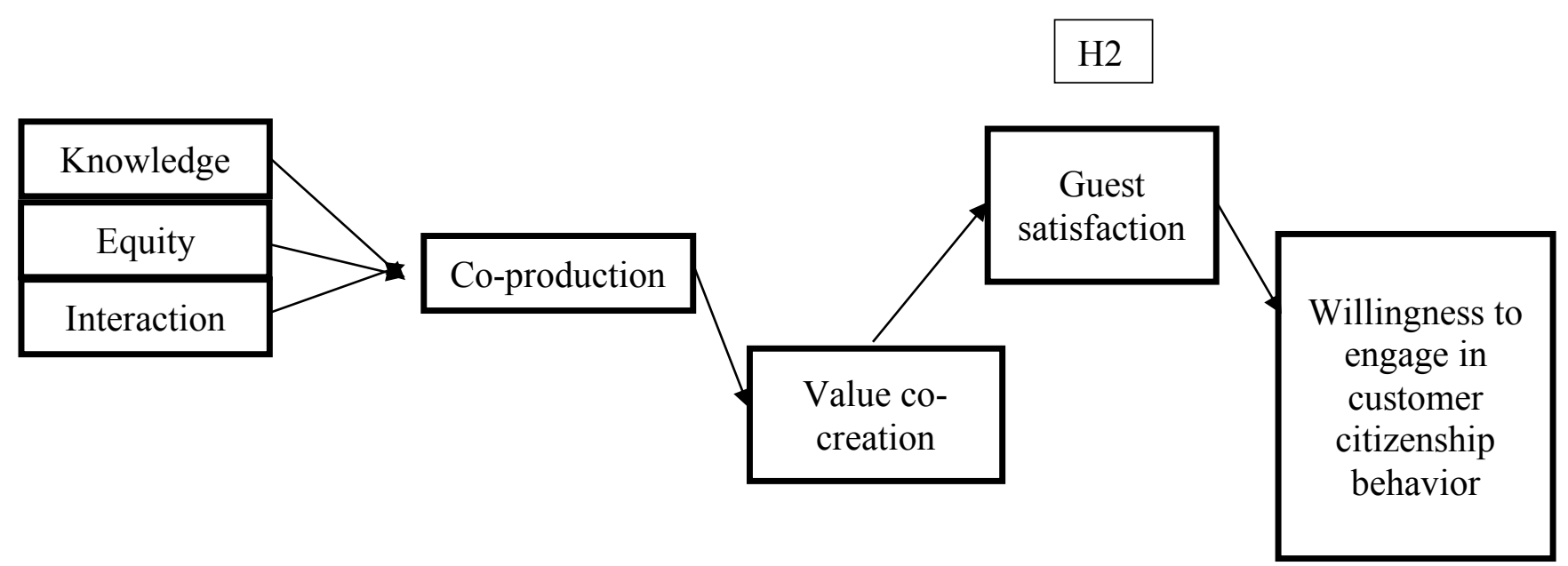




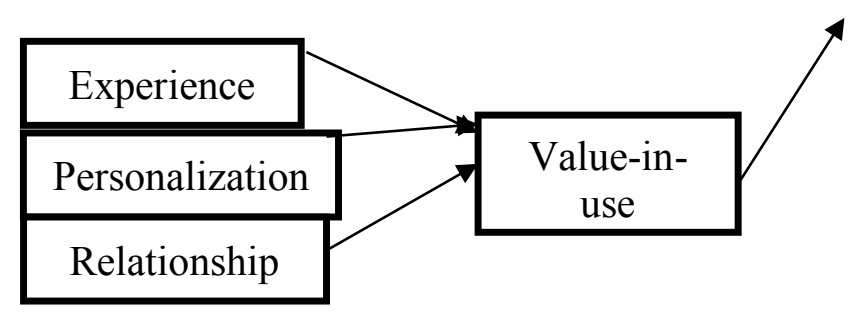

H1

Guest satisfaction within the context of value co-creation and willingness to engage in customer citizenship behavior

Emphasizing the principal role of the guest in hospitality services, earlier studies examined customer satisfaction as a mediator in measures of non-financial performance (e.g. Cronin \& Taylor, 1992). This study explores the mediating role that satisfaction may play in the relationship between value co-creation and customer citizenship behavior. Social exchange theory assumes that social behavior is motivated by a trade-off between perceived costs and benefits (Homans, 1961). Participants in relationships evaluate the costs and benefits from these relationships, (Briggs \& Grisaffe, 2010) and usually decide to sustain the relationships when the benefits are reciprocated (Jiang, Henneberg \& Naudé, 2011). Relevant research has shown that, in the majority of cases, prosocial behavior requires resource sacrifice from customers (Brooker, 1976). Drawing the cost-benefit balance, customers finally pursue activities that lead to a more positive (advantageous) equilibrium.

The trade-off between perceived costs and benefits is relevant to the willingness to engage in customer citizenship behavior. During the value co-creation process, consumers exhibit significant efforts to use resources such as competence or skills (Dang \& Arndt, 2017; Prebensen \& Xie, 2017). Customers are eager to participate in joint service activities, if they anticipate benefits from the relationship (Ennew \& Binks, 1999). Hence, based on social exchange theory (Blau, 1964), guests would be willing to foster and maintain the co-creation relationship with the tourism and hospitality service providers, only if they are satisfied from the experienced trade-off between perceived costs, benefits, acts of kindness and reciprocity.

Previous research show that increased levels of co-production have a relationship with customer satisfaction (Haumann, Güntürkün, Schons \& Wieseke, 2015; Buonincontri, Morvillo, Okumus \& van Niekerk, 2017). Based on the relational exchanges, guests who have favorable perceptions of value co-creation are more satisfied and consequently will have higher willingness to engage in customer citizenship behavior. However, guests who spent resources (e.g. time, knowledge) to co-produce a service but finally do not receive the expected valuein-use, will probably have lower willingness to engage in customer citizenship behavior. For 
example, they may not offer feedback for improvement or may not generate positive user generated content. Therefore, we explore the following hypothesis:

H2. Guest satisfaction mediates the relationship between value co-creation and guests' willingness to engage in customer citizenship behavior.

\section{Methodology}

\section{Research Setting and Data Collection}

The quantitative research design employed an online survey, using a structured questionnaire and a non-probabilistic convenience sample. The selection of cross-sectional survey can be justified given the primary aim of the research is to test the veracity of proposed theoretical effects, thus the use of a convenience sample and cross-sectional surveys may suffice (Hulland, Baumgartner \& Smith, 2018). The questionnaire is answered by 521 members of an online panel of Greek tourists between May and June 2017. The online questionnaire was selected for this study, given that online respondents have a lower dropout rate and produce less incomplete data. However, the exclusive use of an online questionnaire commonly results in obtaining a younger and well-educated sample (Dolnicar, Laesser \& Matus, 2009). Nevertheless, this does not constitute much of a problem for the present study, given that the aim is to explore the relationship between value co-creation and guests' willingness to engage in customer citizenship behavior rather than accurately predict the behavior of a representative sample (Hulland et al., 2018). The participants of the study had visited a lodging facility in Greece or abroad within the three previous months. Participants were asked to provide the name of the lodging facility, the type, and the reason for traveling (leisure or business).

\section{Construct measures}

All measures were adapted from existing scales in relevant literature (see Appendices I and II). Value co-creation was measured by adapting the scale of Ranjan and Read (2014); Guest satisfaction was measured with a single item ("I am satisfied with my decision to use this hospitality service provider") and willingness to engage in customer citizenship behavior incorporated the measurement operationalized by Yi and Gong (2013). Since the study was conducted in Greece, the questionnaire required translation into Greek. Back-translation was used to ensure the accuracy of the version. A thorough pre-test was conducted by involving 20 respondents prior to data collection. No major problems were found to exist in the method, and some minor issues were corrected through instruction changes.

Study sample characteristics 
The sample was almost evenly distributed by gender $(57.1 \%$ female and the remainder male). In terms of age groups, $64.3 \%$ of the respondents were between 18 and 29 years of age, $17.3 \%$ fell into the category of the 30-39 age group, $12.5 \%$ into the $40-49$ age group, $5.6 \%$ into the 50-59 age group, and the rest was 60 years of age or above. Out of them, $47.7 \%$ used lodging facilities once a year or less, 37.7\% 2-4 times per year and 14.6\% more than 4 times per year.

\section{Analysis plan}

The structural parameters in the empirical model were measured by using partial least squares structural equation modelling. More specifically SmartPLS version 3.2.6 (Ringle, Wende \& Becker, 2015), is most appropriate to use when the aim of study is to explore the theoretical effects, the model incorporates both formative and reflective indicators whilst assumptions of multivariate normality cannot be made (Hair, Hult, Ringle \& Sarstedt, 2017). The model and data of this study meet these conditions, since value co-creation is formative and willingness to engage in customer citizenship behavior is reflective.

\section{Results}

Variance inflation factor values of the following sets of constructs were assessed for collinearity: (1) knowledge (3.529), equity (4.247) and interaction (4.208) as predictors of coproduction; (2) experience (2.343), personalization (3.069) and relationship (2.487) as predictors of value-in-use (3); value-in-use (4.689) and co-production (4.689) as predictors of value co-creation; and (4) value co-creation (2.873) and satisfaction (2.873) as predictors of willingness to engage in customer citizenship behavior. All variance inflation factor values were clearly below the threshold of 5. Therefore, collinearity among the predictor constructs is not a critical issue in the structural model. The $\mathrm{R}^{2}$ values of willingness to engage in customer citizenship behavior (0.573) and satisfaction (0.651) can be considered moderate, whereas the $\mathrm{R}^{2}$ value of co-production (0.996), value-in-use (0.998) and value co-creation (0.995) are high.

Following Hair et al. (2017), bootstrapping (5.000 resamples) was used to generate standard errors and t-statistics to evaluate the significance of the parameters. Hypothesis 1 , which states that firms' value co-creation is associated with customer intention to engage in citizenship behavior, is supported $(\beta=0.574, p<0.001)$. Furthermore, value co-creation is associated with customer satisfaction $(\beta=0.807, \mathrm{p}<0.001)$ (see Table I). The bootstrapping results for the total effects are summarized in Table II. Although the total effects of exogenous variables on willingness to engage in customer citizenship behavior are statistically significant, the impact of personalization is higher $(\beta=0.316, p<0.001)$ than the others. Equity $(\beta=0.124$, 
$\mathrm{p}<0.001)$ and interaction $(\beta=0.128, \mathrm{p}<0.001)$ are the next most important (influential) exogenous variables in terms of impact on willingness to engage in customer citizenship behavior.

Table I: Path Coefficients, t Values, Confidence Intervals

\begin{tabular}{|c|c|c|c|c|}
\hline & $\begin{array}{c}\text { Path } \\
\text { Coefficients }\end{array}$ & t Values & $\begin{array}{l}95 \% \text { Confidence } \\
\text { Intervals }\end{array}$ & $\begin{array}{l}\text { Significance } \\
(\mathrm{p}<0.05)^{\mathrm{a}}\end{array}$ \\
\hline $\begin{array}{l}\text { Co-production -> Value co- } \\
\text { creation }\end{array}$ & 0.455 & $6.690 * * *$ & {$[0.313,0.580]$} & YES \\
\hline Equity $->$ Co-production & 0.387 & $5.663 * * *$ & {$[0.246,0.516]$} & YES \\
\hline Experience -> Value-in-use & 0.201 & $4.678 * * *$ & {$[0.121,0.289]$} & YES \\
\hline Interaction $->$ Co-production & 0.407 & $6.633 * * *$ & {$[0.291,0.532]$} & YES \\
\hline Knowledge -> Co-production & 0.265 & $4.825 * * *$ & {$[0.159,0.374]$} & YES \\
\hline Personalization -> Value-in-use & 0.703 & $16.719 * * *$ & {$[0.615,0.780]$} & YES \\
\hline Relationship -> Value-in-use & 0.169 & $4.345 * * *$ & {$[0.091,0.245]$} & YES \\
\hline $\begin{array}{l}\text { Satisfaction -> Willingness to } \\
\text { engage in customer citizenship } \\
\text { behavior }\end{array}$ & 0.215 & $3.507 * * *$ & {$[0.115,0.348]$} & YES \\
\hline $\begin{array}{l}\text { Value co-creation -> } \\
\text { Willingness to engage in } \\
\text { customer citizenship behavior }\end{array}$ & 0.574 & $10.432 * * *$ & {$[0.438,0.658]$} & YES \\
\hline $\begin{array}{l}\text { Value co-creation -> } \\
\text { Satisfaction }\end{array}$ & 0.807 & $49.008 * * *$ & {$[0.764,0.833]$} & YES \\
\hline $\begin{array}{l}\text { Value-in-use -> Value co- } \\
\text { creation }\end{array}$ & 0.571 & $8.544 * * *$ & {$[0.449,0.710]$} & YES \\
\hline
\end{tabular}

$* * * \mathrm{P}<0.001$

${ }^{\text {a }}$ Refers to the bootstrap confidence intervals for significance testing

Table II: Total effects, t Values, Confidence Intervals

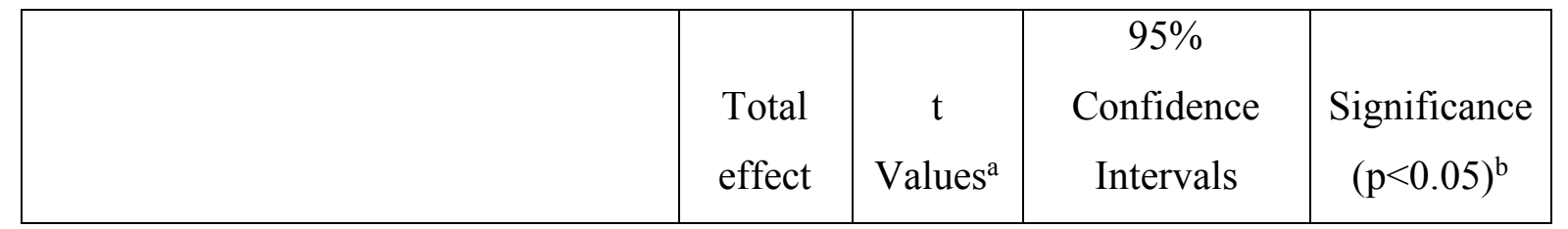




\begin{tabular}{|c|c|c|c|c|}
\hline $\begin{array}{l}\text { Co-production -> Willingness to } \\
\text { engage in customer citizenship } \\
\text { behavior }\end{array}$ & 0.340 & 6.594 & {$[0.229,0.433]$} & YES \\
\hline Co-production $->$ Satisfaction & 0.367 & 6.667 & {$[0.250,0.467]$} & YES \\
\hline $\begin{array}{l}\text { Equity -> Willingness to engage in } \\
\text { customer citizenship behavior }\end{array}$ & 0.132 & 3.921 & {$[0.072,0.203]$} & YES \\
\hline Equity $->$ Satisfaction & 0.142 & 3.881 & {$[0.078,0.220]$} & YES \\
\hline Equity -> Value co-creation & 0.176 & 3.918 & {$[0.099,0.273]$} & YES \\
\hline $\begin{array}{l}\text { Experience -> Willingness to engage } \\
\text { in customer citizenship behavior }\end{array}$ & 0.086 & 4.036 & {$[0.052,0.137]$} & YES \\
\hline Experience -> Satisfaction & 0.093 & 4.116 & {$[0.056,0.147]$} & YES \\
\hline Experience -> Value co-creation & 0.115 & 4.123 & {$[0.070,0.183]$} & YES \\
\hline $\begin{array}{l}\text { Interaction -> Willingness to engage } \\
\text { in customer citizenship behavior }\end{array}$ & 0.138 & 4.932 & {$[0.090,0.200]$} & YES \\
\hline Interaction -> Satisfaction & 0.150 & 5.079 & {$[0.099,0.215]$} & YES \\
\hline Interaction $->$ Value co-creation & 0.185 & 5.066 & {$[0.123,0.265]$} & YES \\
\hline $\begin{array}{l}\text { Knowledge -> Willingness to engage } \\
\text { in customer citizenship behavior }\end{array}$ & 0.090 & 3.887 & {$[0.049,0.141]$} & YES \\
\hline Knowledge -> Satisfaction & 0.098 & 3.911 & {$[0.054,0.151]$} & YES \\
\hline Knowledge -> Value co-creation & 0.121 & 3.927 & {$[0.067,0.189]$} & YES \\
\hline $\begin{array}{l}\text { Personalization -> Willingness to } \\
\text { engage in customer citizenship } \\
\text { behavior }\end{array}$ & 0.300 & 7.133 & {$[0.224,0.392]$} & YES \\
\hline Personalization -> Satisfaction & 0.324 & 7.193 & {$[0.243,0.421]$} & YES \\
\hline Personalization -> Value co-creation & 0.402 & 7.502 & {$[0.307,0.518]$} & YES \\
\hline $\begin{array}{l}\text { Relationship -> Willingness to } \\
\text { engage in customer citizenship } \\
\text { behavior }\end{array}$ & 0.072 & 3.909 & {$[0.040,0.112]$} & YES \\
\hline Relationship -> Satisfaction & 0.078 & 3.940 & {$[0.043,0.121]$} & YES \\
\hline Relationship -> Value co-creation & 0.096 & 3.947 & {$[0.054,0.152]$} & YES \\
\hline $\begin{array}{l}\text { Value Co-Creation -> Willingness to } \\
\text { engage in customer citizenship } \\
\text { behavior }\end{array}$ & 0.747 & 33.236 & {$[0.692,0.783]$} & YES \\
\hline
\end{tabular}




\begin{tabular}{|l|r|r|r|c|}
\hline Value co-creation -> Satisfaction & 0.807 & 49.008 & {$[0.764,0.833]$} & YES \\
\hline $\begin{array}{l}\text { Value-in-use -> Willingness to } \\
\text { engage in customer citizenship } \\
\text { behavior }\end{array}$ & 0.427 & 8.065 & {$[0.329,0.536]$} & YES \\
\hline Value-in-use -> Satisfaction & 0.461 & 8.247 & {$[0.358,0.575]$} & YES \\
\hline
\end{tabular}

${ }^{a}$ All the $t$ values were significant at the level $p<0.001$

${ }^{\mathrm{b}}$ Refers to the bootstrap confidence intervals for significance testing

\section{Mediator analysis}

Both indirect effects are significant, since neither of the $95 \%$ confidence intervals includes zero. The empirical $t$ value of the indirect effect of the value co-creation to willingness to engage in customer citizenship behavior relationship was $0.173(\mathrm{t}=3.486 ; \mathrm{p}<0.001)$. As a next step, the mediation analysis focused on the significance of the direct effects from value co-creation to willingness to engage in customer citizenship behavior. Value co-creation is associated $(\beta=0.574 ; \mathrm{t}=8.340 ; \mathrm{p}<0.001)$ with willingness to engage in customer citizenship behavior. Therefore, satisfaction partially mediates the relationship since both the direct and indirect effects are significant. To further substantiate the type of partial mediation, the product of the direct effect and the indirect effect was computed $(0.574 \cdot 0.173=0.099)$. Hence, satisfaction represents complementary mediation of the relationship from value co-creation to willingness to engage in customer citizenship behavior.

\section{Conclusions and implications}

The primary goal of the present study is to explore the association between value cocreation and willingness to engage in customer citizenship behavior. This paper contributes to the tourism and hospitality literature by applying some of the principles of the service-dominant logic and testing the relevance of social exchange theory to explain the possible association between the aforementioned variables. The results reveal that value co-creation has a strong statistical association with customer citizenship behavior and guest satisfaction.

\section{Theoretical Implications}

This study contributes to existing literature on value co-creation and customer citizenship behavior in several ways. This study measures co-production but also 'value-inuse' and finds that both dimensions of value co-creation are significant but value-in-use (0.449) 
has a stronger correlation to the willingness to engage in customer citizenship behavior, than co-production (0.316). Furthermore, the investigation of dimensions of co-production and value-in-use provides more in-depth understanding of the factors that possibly contribute in the value co-creation. The total effect of personalization (0.316), one of the dimensions of valuein-use, is much higher than the other dimensions. The importance of personalization has already been discussed in the tourism and hospitality literature (Buhalis \& Amaranggana, 2015; Buhalis \& Foerste, 2015) highlighting benefits such as emotional and psychical comfort for the tourist, as well as customer loyalty. The stronger association of personalization in the context of this study should not underestimate the significance of other dimensions of value cocreation. In different contexts (e.g. events), some dimensions of value co-creation may have stronger associations with the guests' willingness to engage in customer citizenship behavior. For instance, in music festivals the dimension of relationship can play a more important role in the creation of value-in-use than in hotels.

This study extends current literature on social exchange theory in the fields of tourism and hospitality. Social exchange theory has been used in the host community studies, (e.g. Nunkoo \& Ramkissoon, 2012) but also in voluntary tourism associations (e.g. Paraskevaidis \& Andriotis, 2017). The reciprocal nature of citizenship behavior that has been explored in other contexts (e.g. employees) is also been explored and identified in this paper. It seems that customers are eager to engage in constructive behaviors to get intrinsic or extrinsic rewards, as long as they feel that they gain higher value-in-use from their participation in the service production and delivery process. This is in accordance with social exchange theory. The role of social exchange theory and reciprocity is similar to the host community support towards the tourism development when it has positive economic, environmental, and sociocultural impacts for them (e.g. Bimonte \& Punzo, 2016).

The study also identifies that value co-creation has strong correlation with guest satisfaction (Mathis et al., 2016; Prebensen \& Xie, 2017). The satisfaction is then associated to guests' willingness to engage in customer citizenship behavior. We identify that satisfaction can possibly play the role of complementary mediator in the relationship of value co-creation and willingness to engage in customer citizenship behavior, as well. The "give and take" aspect of social exchange theory can depend on the balance between costs and benefits, as already argued in other contexts (Homans, 1961; Briggs \& Grisaffe, 2010). Hotel guests can possibly reward hospitality organizations that provide excellent value and satisfy them with the offered value co-creation process. The reward is not necessarily related to personal intention to return or actual repurchase intention but with the possible dimensions of customer citizenship 
behavior such as positive word of mouth, feedback, assisting other customers, participation in online hotel activities.

\section{Practical Implications}

Tourism and hospitality organizations should encourage and formulate co-creation processes based on the "give and take" characteristic (social exchange theory) in their relationship with tourists, given that there is probably strong association between value cocreation, guest satisfaction and willingness to engage in customer citizenship behavior. Significant relationships with tourists are developed where there is an exchange of activities and value is being co-created. To maximize the benefit of co-creation, information should be shared and data on preferences should be collected and analyzed. Willingness to engage in customer citizenship behavior and its outcomes are only a few areas from which tourism and hospitality organizations may benefit. These outcomes often include a combination of constructive customer feedback, helping behavior towards other tourists, positive word-ofmouth and overall tolerance in the case of lower levels of future satisfaction with the service provision.

Customers, employees co-creating experiences, beyond the functional benefit, should be carefully mixed and filtered through the lens of interaction, equity and personalization, as they all have associations with willingness to engage in customer citizenship behavior. These dimensions entail a high level of engagement, control, sharing and reciprocity. For example, remembering a guest's preference and making the necessary modifications for the next visit can co-create "wow"-experiences and make customers feel at home. Co-creation can only be generated and expressed through empathy and creates feelings that are beyond the commercial spectrum. In this vein, co-creation is encouraged with all stakeholders and actors towards maximizing benefit for all.

According to the results of this exploratory study, organizations should provide opportunities for guests to express their desires or participate in the co-creation process. The various touchpoints and considerable interactions in the tourism and hospitality context offer the ideal platform for co-production. Value-in-use can flourish through engaging customers in the joy of co-creation. Tourism and hospitality organizations therefore should engage with their visitors before, during and after the travel experience, to understand their preferences, desires and prerequisites, and encourage a dynamic dialog in real-time, whilst the co-creation takes place (Buhalis and Sinarta, 2019). A range of contextual information should be taken into account in co-creation, including: familiarity with the place, topics of interest, disabilities or 
specific abilities, emotional state of the guest. The social context mobile marketing enables marketers to increase value for all stakeholders at the destination (Buhalis, \& Foerste, 2015). To foster such interactions, hospitality and tourism firms should always keep customers updated via social media and open communication channels. Technology is a key parameter in the co-creation of enhanced experiences on the grounds and empowers the employee-customer, customer-firm, and customer-to-customer interaction (Neuhofer et al., 2015). Asking guests to perform some parts of animation, participate in cooking demonstrations, or even sport activities organized between guests and employees, are some examples commonly practiced in the industry.

Sharing of tourists' knowledge with tourism and hospitality organizations is critical in the value co-creation process. Researchers agree that innovation depends on knowledge sharing within tourism networks (Cooper, 2006, 2018; Hoarau \& Kline, 2014). Tourism and hospitality organizations should provide the necessary processes and platforms for the guests to procure dynamic feedback. They should instantly share their knowledge within their ecosystem in order to improve the value co-created from the services in real time (Buhalis \& Sinarta, 2019). These processes, procedures and platforms should facilitate the advocacy as well as the assistance of other guests and ensure agile management, where everything is constantly improving.

Viewing employees as operant resources in the co-creation process, makes their effective training and education of critical importance. Keeping employees happy and engaged in this process is progressively becoming more critical (Stamolampros et al., 2019). Given that value co-creation is a process that depends highly on the communication skills of employees, the success of value co-creation also rests on the acquisition, assimilation, transformation, and exploitation capabilities of the service provider (Berger, Möslein, Piller, \& Reichwald, 2005). Tourism and hospitality service providers should support employee-customer engagement so they may obtain the necessary information about what guests want from the hotel (acquisition), as well as increasing their flexibility in creating a more personalized experience and relationship (assimilation).

The level of education and training of front-line staff, their behavior and actions are evidenced in the level of uniqueness of the value that emerges for each visitor. This should also influence recruitment processes to employ the right staff and the development of engagement as a core element of a brand. In addition, online consumer reviews, such as the major online review platforms, namely TripAdvisor, Expedia, Booking.com and Yelp, can also provide useful information, regardless their considerable variation in terms of their linguistic characteristics, semantic features, sentiment, rating, and usefulness (Xiang, Du, Ma \& Fan, 
2017). Guest experience and satisfaction are inherently connected and big data analytics can generate new insights (Xiang et al., 2015).

However, co-production comes with some risks. Customer citizenship behavior, such as word-of-mouth is not a homogeneous activity (Ring, Tkaczynski \& Dolnicar, 2016). Therefore, the development of these platforms should always assume that different people display different customer citizenship behavior. A "working consumer" may feel that his/her participation in value creation is actually a form of exploitation carried out by the service provider (Cova \& Dalli, 2009). Other guests may be annoyed, if privileges are only offered to a selected few. Therefore, the experience of all guests should be seriously considered, providing the desired level or participation and involvement to the appropriate guests. Providing the right level of engagement to the right guest is often complex and may be as a result of a balancing act. The outcome however, may lead to highly effective engagement and satisfaction, triggering reciprocity and willingness to engage in customer citizenship behavior.

\section{Future Research}

Surveys for data collection have inherent dangers and limitation as suggested by Dolnicar (2018). According to Van der Stede (2014, p. 568): “[...] an observed correlation between outcomes and their presumed causes does not establish causation. Strictly speaking, only experiments with randomization can expose causal relationships. But this should not render all other approaches short of this experimental standard useless". We acknowledge that the results of our study should be confirmed by using experimental studies that can actual confirm the causation between the investigated variables. However, the limitation of our study "should not render all other approaches short of this experimental standard useless" (Van der Stede, 2014, p. 568). Our study explores the correlation between some variables that have not been investigated so well in the literature and it offers the necessary building block to future work investigating causation (Dolnicar \& Ring, 2014).

The positive outcomes of customer participation depend on customers' individual characteristics, firms' support and culture, and employees' involvement (Grissemann \& Stokburger-Sauer, 2012). Previous studies indicate that agreeableness and extraversion affect empathic re-actions in people and consequently customer satisfaction and citizenship behavior (Anaza, 2014). Therefore, customer and employee personality may influence the value cocreation - customer citizenship behavior relationship, setting the future research agenda in this field. Investigating cultural and individual differences of reciprocity is another avenue for future studies to expand the results of the present contribution. Individuals differ in the extent 
to which they endorse reciprocity (Clark \& Mills, 1979). Thus, the role of exchange ideology should be explored, given that it has already been found to influence citizenship behavior (Witt, 1991). Moreover, the positive association of guest satisfaction with willingness to engage in customer citizenship behavior should be further investigated. It has been argued that there are many factors (e.g. variety seeking) that can influence the effect of satisfaction with behavioral intention (Dolnicar, Coltman \& Sharma, 2015).

Furthermore, future studies should investigate the factors that affect tourism and hospitality co-creation, the service climate and customer complexity ( $\mathrm{Ma}, \mathrm{Gu}$, Wang \& Hampson, 2017) as conditional factors of the relationship between value co-creation and customer citizenship behavior. Firm motives for the higher value co-creation and firm reputation may also explain more the value co-creation - customer citizenship behavior relationship, especially when it comes to unpacking the critical debate of consumer exploitation. Experimental studies can be very useful to confirm whether the firm motives can play significant role in this relationship. Moreover, engagement as part of brand character is something that can be investigated to gain a better understanding and greater insights about the value co-creation - customer citizenship behavior relationship (Black \& Veloutsou, 2017). In light of emerging literature on the impact of co-creation on destination authenticity (e.g. Ross et al., 2017; Szmigin et al., 2017), future studies should also investigate the role of value cocreation and customer citizenship behavior on authenticity.

A wider exploration (zoom-out) to the broad service ecosystems perspective is necessary for future studies. The updated version of the service-dominant logic framework has led to a fruitful academic debate about service ecosystems focusing on institutions - rules, norms, meanings, symbols, practices, and similar aides to collaboration - and institutional logics (Vargo \& Lusch, 2016). The service-dominant logic ecosystem view will provide a deeper and wider perspective of hospitality and tourism research. It will enable and compel researchers to zoom out beyond dyadic exchange encounters (micro-level) and to view value as being co-created in networks, through (eco)systems of service-for-service exchanges. However, zooming out to the broader service ecosystem view often makes it difficult to pinpoint specific drivers of value co-creation (Wieland, Koskela-Huotari \& Vargo, 2016).

This study explores the value co-creation - willingness to engage in customer citizenship behavior from a reflective perspective. The usage of PARTicipative inquiry (Ingram, Caruana, \& McCabe, 2017) provides very promising directions for future research, in order to explore the impact of value co-creation on guest satisfaction and customer citizenship behavior pre-, on- and post-trip. This methodology can facilitate the measurement of the actual 
customer citizenship behavior, something that hasn't been investigated in the current study. This would answer the call of Dolnicar $(2015$, p. 262) for "dedicate more time and effort to the study of actual tourist behavior". Furthermore, the appropriate analysis of big data has the potential to increase the validity of customer citizenship behavior measurement. Similar methodologies may facilitate further examination of the whole experience, including the various phases of value co-creation and actual customer citizenship behavior (prospective, active and reflective).

\section{References}

Anaza, A. N. (2014). Personality antecedents of Customer Citizenship Behaviours in Online Shopping Situations. Psychology \& Marketing, 31(4), 251-263.

Barnes, S. J., Mattsson, J., \& Sørensen, F. (2014). Destination brand experience and visitor behavior: Testing a scale in the tourism context. Annals of Tourism Research, 48,121-139.

Berger, C., Möslein, K., Piller, F., \& Reichwald, R. (2005). Co-designing modes of cooperation at the customer interface: Learning from exploratory research. European Management Review, 2(1), 170-167.

Bimonte, S., \& Punzo, L. F. (2016). Tourist development and host-guest interaction: An economic exchange theory. Annals of Tourism Research, 58, 128-139.

Binkhorst, E., \& Den Dekker, T. (2009). Agenda for co-creation tourism experience research. Journal of Hospitality Marketing \& Management, 18(2-3), 311-327.

Black, I., \& Veloutsou, C. (2017). Working consumers: co-creation of brand identity, consumer identity and brand community identity. Journal of Business Research, 70, 416429.

Blau, P. M. (1964), Exchange and power in social life, John Wiley, NY.

Bove, L. L., Pervan, S.J., Beatty, S. E., \& Shiu, E. (2009). Service worker role in encouraging customer organizational citizenship behaviours, Journal of Business Research, 62(7), 698705 .

Briggs, E., \& Grisaffe, D. (2010). Service performance-loyalty intentions link in a businessto-business context: The role of relational exchange outcomes and customer characteristics. Journal of Service Research, 13(1), 37-51.

Brooker, G. (1976). The self-actualizing socially conscious consumer. Journal of Consumer Research, 3 (2,1), 107-122.

Bryce, D., Murdy, S. \& Alexander, M. (2017). Diaspora, authenticity and the imagined past. Annals of Tourism Research, 66, 49-60. 
Buhalis D., \& Amaranggana A. (2015). Smart tourism destinations enhancing tourism experience through personalisation of services. in: Tussyadiah I., Inversini A. (Eds), Information and communication technologies in tourism, Springer, 377-389.

Buhalis, D., \& Foerste, M. (2015). SoCoMo marketing for travel and tourism: Empowering co-creation of value. Journal of Destination Marketing \& Management, 4(3), 151-161.

Buhalis, D., \& Sinarta, Y. (2019). Real-time cocreation and nowness service: Lessons from tourism and hospitality, Journal of Travel \& Tourism Marketing, 30, https://doi.org/10.1080/10548408.2019.1592059

Buonincontri, P., Morvillo, A., Okumus, F. \& van Niekerk, M. (2017). Managing the experience co-creation process in tourism destinations: Empirical findings from Naples. Tourism Management, 62, 264-277.

Cabiddu, F., Lui, T-W., \& Piccoli, G. (2013). Managing value co-creation in the tourism industry. Annals of Tourism Research, 42, 86-107

Chan, K. W., Yim, C. K., \& Lam, S. S. K. (2010). Is customer participation in value creation a double-edged sword? Evidence from professional financial services across cultures. Journal of Marketing, 74(3), 48-64.

Chen, W. J. (2016). The model of service-oriented organizational citizenship behavior among international tourist hotels. Journal of Hospitality and Tourism Management, 29, 24-32.

Clark, M. S., \& Mills, J. (1979). Interpersonal attraction in exchange and communal relationships. Journal of Personality \& Social Psychology, 37(1), 12-24.

Cooper, C. (2006). Knowledge management and tourism. Annals of Tourism Research, 33(1), $47-64$.

Cooper, C. (2018). Managing tourism knowledge: a review. Tourism Review, 73 (4), $507-$ 520.

Coulson, A. B., Maclaren, A.C., Mckenzie, S., \& O'Gorman, K. D. (2014). Hospitality codes and social exchange theory: The pashtunwali and tourism in Afghanistan. Tourism Management, 45, 134-141.

Cova, B., \& Dalli, D. (2009). Working consumers: The next step in marketing theory? Marketing Theory, 9(3), 315-339.

Cronin Jr, J. J., \& Taylor, S. A. (1992). Measuring service quality: A reexamination and extension. Journal of Marketing, 56(3), 55-68.

Cropanzano, R., \& Mitchell, M. S. (2005). Social exchange theory: An interdisciplinary review. Journal of Management, 31(6), 874-900.

Dang, A., \& Arndt, A. D. (2017). How personal costs influence customer citizenship behaviors. Journal of Retailing and Consumer Services, 39, 173 - 181.

Dolnicar, S., \& Ring, A. (2014). Tourism marketing research: Past, present and future. Annals of Tourism Research, 47, 31-47. 
Dolnicar, S. (2015). In future, I would love to see ... a reflection on the state of quantitative tourism research. Tourism Review, 70(4), 259 - 263.

Dolnicar, S. (2018). A reflection on survey research in hospitality. International Journal of Contemporary Hospitality Management, 30(11), 3412-3422.

Dolnicar, S., Coltman, T. \& Sharma, R. (2015). Do satisfied tourists really intend to come back? three concerns with empirical studies of the link between satisfaction and behavioral intention. Journal of Travel Research, 54(2), 152-178.

Dolnicar, S., Laesser, C., \& Matus, M. (2009). Online versus paper format effects in tourism surveys. Journal of Travel Research, 47(3), 295-316.

Edvardsson, B., Gustafsson, A., \& Roos, I. (2005). Service portraits in service research: A critical review. International Journal of Service Industry Management, 16(1), 107-121.

Ennew, C. T., \& Binks, M. R. (1999). Impact of participative service relationships on quality, satisfaction and retention: An exploratory study. Journal of Business Research, 46(2), 121132.

Grissemann U. S., \& Stokburger-Sauer, N. E. (2012). Customer co-creation of travel services: The role of company support and customer satisfaction with the co-creation performance. Tourism Management, 33, 1483-1492.

Grönroos, C., \& Voima, P. (2013). Critical service logic: Making sense of value creation and co-creation. Journal of Academy Marketing Science, 41(2), 133-150.

Groth, M. (2005). Customers as good soldiers: Examining citizenship behaviors in internet service deliveries. Journal of Management, 31(1), 7-27.

Hair, J. F., Hult, G. T. M., Ringle, C. M., \& Sarstedt, M. (2017). A primer on partial least squares structural equation modeling (PLS-SEM), 2nd Ed., Sage: Thousand Oaks.

Hamilton, K., \& Alexander, M. (2013). Organic community tourism: A cocreated approach. Annals of Tourism Research, 42, 169-190.

Haumann, T., Güntürkün, P., Schons, L. M., \& Wieseke, J. (2015). Engaging customers in coproduction processes: How value-enhancing and intensity-reducing communication strategies mitigate the negative effects of coproduction intensity. Journal of Marketing, 79(6), $17-33$.

Hoarau, H., \& Kline, C. (2014). Science and industry: Sharing knowledge for innovation. Annals of Tourism Research, 46, 44-61.

Homans, G. C. (1961). Social Behavior: Its Elementary Forms, New York: Harcourt Brace.

Hoyer, D. H., Chandy, R., Dorotic, M., Krafft, M. \& Singh, S. S. (2010). Consumer cocreation in new product development. Journal of Service Research, 13(3), 283-296.

Hulland, J., Baumgartner, H., \& Smith, K.M. (2018). Marketing survey research best practices: Evidence and recommendations from a review of JAMS articles. Journal of Academy of Marketing Science, 46(1), 92-108 
Ingram, C., Caruana, R., \& McCabe, S. (2017). PARTicipative inquiry for tourist experience. Annals of Tourism Research, 65, 13-24.

Jansson, A. (2018). Rethinking post-tourism in the age of social media. Annals of Tourism Research, 69, 101-110.

Jiang, Z., Henneberg, S. C., \& Naudé, P. (2011). The importance of trust vis-à-vis reliance in business relationships: some international findings. International Marketing Review, 28(4), 318-339.

Kaynak, E., \& Marandu, E. E. (2006). Tourism market potential analysis in Botswana: A Delphi study. Journal of Travel Research, 45(2), 227-237.

Kelley, S.S., Donnelly, J.H. \& Skinner, S.J. (1990), Customer participation in service production and delivery, Journal of Retailing, 66(3), 315-335.

Lam, D., \& So, A. (2013). Do happy tourists spread more word-of-mouth? The mediating role of life satisfaction. Annals of Tourism Research, 43, 624-650.

Lee, Yi-H., Hsiao, C., \& Chen, Y. C. (2017). Linking positive psychological capital with customer value co-creation. International Journal of Contemporary Hospitality Management, 29(4), 1235-1255.

Li, M., \& Hsu, C. H. C. (2018). Customer participation in services and employee innovative behavior: The mediating role of interpersonal trust. International Journal of Contemporary Hospitality Management, 30(4), 2112-2131.

Liu, J. S. \& Tsaur, S. H. (2014). We are in the same boat: tourist citizenship behaviors. Tourism Management, 42, 88-100.

Lusch, R. F., \& Vargo, S. L. (2006). Service-dominant logic: reactions, reflections and refinements. Marketing theory, 6(3), 281-288.

Ma, S., Gu, H., Wang, Y., \& Hampson, D. P. (2017). Opportunities and challenges of value co-creation: The role of customer involvement in hotel service development. International Journal of Contemporary Hospitality Management, 29(12), 3023-3043.

Mathis, E., F., Kim, H., Uysal, M., Sirgy, J. M., \& Prebensen, N. K. (2016). The effect of cocreation experience on outcome variable. Annals of Tourism Research, 57, 62-75.

McCable, S., \& Stokoe, E. (2010), Have You Been Away? Holiday Talk in Everyday Interaction, Annals of Tourism Research, 37(4), 1117-1140.

Mills, P.K. \& Moberg, D.J. (1982), Perspective on the technology of service operations, Academy of Management Review, 7, 467-478.

Mostafanezhad, M., \& Norum, R. (2018), Tourism in the post-selfie era, Annals of Tourism Research, 70, 131-132.

Nadiri, H., \& Tanova, C. (2010). An investigation of the role of justice in turnover intentions, job satisfaction, and organizational citizenship behavior in the hospitality industry.

International Journal of Hospitality Management, 29(1), 33-41. 
Neuhofer, B., Buhalis, D., \& Ladkin, A. (2015). Smart technologies for personalized experiences: a case study in the hospitality domain. Electronic Markets, 25(3), 243-254.

Nunkoo, R., \& Ramkissoon, H. (2012). Power, trust, social exchange and community support. Annals of Tourism Research, 39(2), 997-1023.

Paraskevaidis, P., \& Andriotis, K. (2017). Altruism in tourism: Social exchange theory vs altruistic surplus phenomenon in host volunteering. Annals of Tourism Research, 62, 26-37.

Park, S., \& Nicolau, J. L. (2017). Effects of general and particular online hotel ratings. Annals of Tourism Research, 62, 114-116.

Payne, A. F., Storbacka, K., \& Frow, P. (2008). Managing the co-creation of value. Journal of the Academy of Marketing Science, 36(1), 83-96.

Prebensen, N. K., \& Xie, J. (2017). Efficacy of co-creation and mastering on perceived value and satisfaction in tourists' consumption. Tourism Management, 60, 166-176.

Prebensen, N. K., Vittersø, J., \& Dahl, T. I. (2013). Value co-creation significance of tourist resources. Annals of Tourism Research, 42, 240-261.

Preikschas, M. W., Cabanelas, P., Rüdiger, K., \& Lampón, J. F. (2017). Value co-creation, dynamic capabilities and customer retention in industrial markets. Journal of Business \& Industrial Marketing, 32(3), 409-420.

Ranjan, K. R. \& Read, S. (2014). Value co-creation: Concept and measurement. Journal of the Academy of Marketing Science, 44(3), 290-315.

Revilla-Camacho, M. A., Vega-Vázquez, M., \& Cossío-Silva, F. J. (2015). Customer participation and citizenship behavior effects on turnover intention. Journal of Business Research, 68(7), 1607-1611.

Rihova, I., Buhalis, D., Gouthro, M. B., Moital, M. (2018). Customer-to-customer co-creation practices in tourism: Lessons from customer-dominant logic. Tourism Management, 67, 362375.

Rihova, I., Buhalis, D., Moital, M., \& Gouthro, M-B. (2015). Conceptualising customer-tocustomer value co-creation in tourism. International Journal of Tourism Research, 17, 356363.

Ring, A., Tkaczynski, A., \& Dolnicar, S. (2016). Word-of-mouth segments: Online, offline, visual or verbal? Journal of Travel Research, 55(4), 481-492.

Ringle, C. M., Wende, S., \& Becker, J.-M. (2015), "SmartPLS 3." Boenningstedt: SmartPLS $\mathrm{GmbH}, \underline{\text { http://www.smartpls.com. }}$

Roberts, D., Hughes, M., \& Kertbo, K. (2014). Exploring consumers' motivations to engage in innovation through co-creation activities. European Journal of Marketing, 48(1/2), $147-$ 169.

Ross, D., Saxena, G., Correia, F., \& Deutz, P. (2017). Archaeological tourism: A creative approach. Annals of Tourism Research, 67, 37-47. 
Sfandla, C., \& Björk, P. (2013). Tourism experience network: Co-creation of experiences in interactive processes. International Journal of Tourism Research, 15(5), 495-506.

Smith, L.J. (1994). The tourism Product, Annals of Tourism Research, 21(3), 582-595.

Stamolampros, P., Korfiatis, N., Chalvatzis, K., Buhalis D. (2019). Harnessing the "wisdom of employees" from online reviews. Annals of Tourism Research

https://doi.org/10.1016/j.annals.2019.02.012

Szmigin, I., Bengry-Howell, Morey, Y., Griffin, C., \& Riley, S. (2017). Socio-spatial authenticity at co-created music festivals. Annals of Tourism Research, 63, 1-11.

Tan, S.-W., Kung, S-F., \& Luh, D-B. (2013). A model of 'creative experience' in creative tourism. Annals of Tourism Research, 41, 153-174.

Tu, Y., Neuhofer, B., \& Viglia, G. (2018). When co-creation pays: Stimulating engagement to increase revenues. International Journal of Contemporary Hospitality Management, 30(4), 2093-2111.

Tung, V. W. S., Chen, Po-Ju., \& Schuckert, M. (2017). Managing customer citizenship behaviour: The moderating roles of employee responsiveness and organizational reassurance. Tourism Management, 59, 23-35.

Van der Stede, W.A. (2014). A manipulationist view of causality in cross-sectional survey Research. Accounting, Organizations and Society, 39(7), 567-574.

Van Doorn, J., Lemon, K. N., Mittal, V., Nass, S., Pick, D., Pirner, P., \& Verhoef, P. C. (2010). Customer engagement behaviour: Theoretical foundations and research directions. Journal of Service Research, 13(3), 253-266.

Vargo, S. L., \& Lusch, R. F. (2016). Institutions and axioms: an extension and update of service-dominant logic. Journal of the Academy of Marketing Science, 44(5), 5-23.

Viglia, G., Minazzi, R., \& Buhalis, D. (2016). The influence of e-word-of-mouth on hotel occupancy rate. International Journal of Contemporary Hospitality Management, 28(9), 2035-2051.

Wieland, H., Koskela-Huotari, K., \& Vargo, S. L. (2016). Extending actor participation in value creation: an institutional view. Journal of Strategic Marketing, 24(3-4), 210-226.

Williams, N., Ferdinand, N., Inversini, A., Buhalis, D. (2015). Community crosstalk: An exploratory analysis of destination and festival eWOM on Twitter. Journal of Marketing Management, 31(9-10), 1113-1140.

Williams, N., Inversini; A., Buhalis, D., Ferdinand, N. (2017). Destination eWOM A macro and meso network approach?. Annals of Tourism Research, 64, 87-101.

Witt, A. L. (1991). Exchange ideology as a moderator of job attitudes-organizational citizenship behaviors relationships. Journal of Applied Social Psychology, 18, 1490-1501. 
Xiang, Z., Du, Q., Ma, Y., \& Fan, W. (2017). A comparative analysis of major online review platforms: Implications for social media analytics in hospitality and tourism. Tourism Management, 58, 51-65.

Xiang, Z., Schwartz, Z., Gerdes Jr, J. H., \& Uysal, M. (2015). What can big data and text analytics tell us about hotel guest experience and satisfaction?. International Journal of Hospitality Management, 44, 120-130.

Xie, C., Bagozzi, R. P., \& Troye, S. V. (2008). Trying to prosume: Toward a theory of consumers as co-creators of value. Journal of the Academy of Marketing Science, 36(1), 109122.

Xu, H., Liu, Y., \& Lyu, X. (2018). Customer value co-creation and new service evaluation: The moderating role of outcome quality. International Journal of Contemporary Hospitality Management, 30(4), 2020-2036.

Yi, Y., \& Gong, T. (2013). Customer value co-creation behavior: Scale development and validation. Journal of Business Research, 66(9), 1279-1284.

Yi, Y., Nataraajan, R., \& Gong, T. (2011). Customer participation and citizenship behavioral influences on employee performance, satisfaction, commitment, and turnover intention. Journal of Business Research, 64, 87-95.

Zhang, H., Gordon, S., Buhalis, D., \& Ding, X. (2018). Experience value cocreation on destination online platforms. Journal of Travel Research, 57(8), 1093-1107.

Zhang, X., \& Chen, R. (2008). Examining the mechanism of the value co-creation with customers. International Journal of Production Economics, 116(2), 242-250.

Zoghbi-Manrique-de-Lara, P., Suárez-Acosta, M. A., \& Aguiar-Quintana, T. (2014). Hotel guests' responses to service recovery how loyalty influences guest behavior. Cornell Hospitality Quarterly, 55(2), 152-164.

\section{Appendices - Questionnaire Scales}

I. Willingness to Engage in Customer Citizenship Behavior (Yi and Gong, 2013)

\begin{tabular}{|c|c|}
\hline \multirow{3}{*}{ Advocacy } & $\begin{array}{l}\text { I will say positive things about the hospitality service provider and the employee to } \\
\text { others. }\end{array}$ \\
\hline & I will recommend the hospitality service provider and the employee to others. \\
\hline & I will encourage friends and relatives to use this hospitality service provider. \\
\hline \multirow[b]{2}{*}{ Feedback } & $\begin{array}{l}\text { If I have a useful idea on how to improve service, I will let this hospitality service } \\
\text { provider know. }\end{array}$ \\
\hline & $\begin{array}{l}\text { When I receive good service from this hospitality service provider, I will comment } \\
\text { about it. }\end{array}$ \\
\hline
\end{tabular}




\begin{tabular}{|l|l|}
\hline \multirow{4}{*}{ Helping } & $\begin{array}{l}\text { When I experience a problem, I will let this hospitality service provider know about } \\
\text { it. }\end{array}$ \\
\hline \multirow{5}{*}{ Tolerance } & $\begin{array}{l}\text { I will assist other customers if they need my help. } \\
\text { problems. }\end{array}$ \\
\cline { 2 - 3 } & $\begin{array}{l}\text { I will help other customers of this hospitality service provider if they seem to have } \\
\text { correctly. }\end{array}$ \\
\cline { 2 - 3 } & $\begin{array}{l}\text { I will give advice to other customers this hospitality service provider. } \\
\text { willing to put up with it. }\end{array}$ \\
\cline { 2 - 3 } & $\begin{array}{l}\text { If the employee of this hospitality service provider will make a mistake during } \\
\text { service delivery, I will be willing to show patience. }\end{array}$ \\
\cline { 2 - 3 } & $\begin{array}{l}\text { If I have to wait longer than I normally expected to receive the service from this } \\
\text { hospitality service provider, I will be willing to adapt. }\end{array}$ \\
\hline
\end{tabular}

II. Value Co-Creation (Ranjan and Read, 2014)

\begin{tabular}{|c|c|}
\hline \multirow[t]{4}{*}{ Knowledge } & $\begin{array}{l}\text { The hospitality service provider was open to my ideas and suggestions about its } \\
\text { existing services or towards developing new services. }\end{array}$ \\
\hline & $\begin{array}{l}\text { The hospitality service provider provided sufficient illustrations and } \\
\text { information to me with regards to the services }\end{array}$ \\
\hline & $\begin{array}{l}\text { I would willingly spare time and effort to share my ideas and suggestions with } \\
\text { the hospitality service provider in order to help it further improve its products } \\
\text { and processes }\end{array}$ \\
\hline & $\begin{array}{l}\text { The hospitality service provider provided me with the suitable environment and } \\
\text { opportunity to offer suggestions and ideas }\end{array}$ \\
\hline \multirow[t]{4}{*}{ Equity } & $\begin{array}{l}\text { The hospitality service provider had an easy access to the information about my } \\
\text { preferences. }\end{array}$ \\
\hline & $\begin{array}{l}\text { The processes at this hospitality service provider are aligned with my } \\
\text { requirements (i.e. the way I wish them to be) }\end{array}$ \\
\hline & $\begin{array}{l}\text { The hospitality service provider considered my role to be as important as its } \\
\text { own in the process }\end{array}$ \\
\hline & We shared an equal role in determining the final outcome of the process. \\
\hline \multirow[t]{3}{*}{ Interaction } & During the process I could conveniently express my specific requirements. \\
\hline & $\begin{array}{l}\text { The hospitality service provider conveyed to its consumers the relevant } \\
\text { information } \\
\text { related to the process }\end{array}$ \\
\hline & $\begin{array}{l}\text { The hospitality service provider allowed sufficient consumer interaction in its } \\
\text { business processes (product development, marketing, assisting other customers, } \\
\text { etc.) }\end{array}$ \\
\hline
\end{tabular}




\begin{tabular}{|c|c|}
\hline & $\begin{array}{l}\text { In order to get maximum benefit from the service, I had to play a proactive role } \\
\text { during my interaction (i.e., I have to apply my skill, knowledge, time, etc.) }\end{array}$ \\
\hline \multirow[t]{3}{*}{ Experience } & It was a memorable experience for me which lasted for quite a while. \\
\hline & $\begin{array}{l}\text { Depending upon the nature of my own participation, my experiences in the } \\
\text { process might be different from those of other customers. }\end{array}$ \\
\hline & $\begin{array}{l}\text { It was possible for a consumer to improve the process by experimenting with } \\
\text { and trying new things. }\end{array}$ \\
\hline \multirow[t]{4}{*}{ Personalization } & $\begin{array}{l}\text { The benefit, value, or fun from the service depended on the user and the usage } \\
\text { condition. }\end{array}$ \\
\hline & The party tried to serve the individual needs of each of its consumer. \\
\hline & $\begin{array}{l}\text { Different consumers, depending on their taste, choice, or knowledge, involve } \\
\text { themselves differently in the service. }\end{array}$ \\
\hline & The party provided an overall good experience, beyond the "functional" benefit. \\
\hline \multirow[t]{4}{*}{ Relationship } & $\begin{array}{l}\text { The hospitality service provider's extended facilitation is necessary for } \\
\text { consumers to fully enjoy the service. }\end{array}$ \\
\hline & I felt an attachment or relationship with the party. \\
\hline & $\begin{array}{l}\text { There was usually a group, a community, or a network of consumers who were } \\
\text { fans of the hospitality service provider. }\end{array}$ \\
\hline & $\begin{array}{l}\text { The hospitality service provider was renowned because its consumers usually } \\
\text { spread positive word about it in their social networks }\end{array}$ \\
\hline
\end{tabular}

